\title{
Pendekatan ANP dalam Penanganan Resiko Kebencanaan Daerah Pertambangan di Wilayah Blitar, Jawa Timur
}

\author{
Erlin Windia Ambarsari ${ }^{1, *}$, Diyan Parwatiningtyas ${ }^{2)}$, Yogi Wiratomo ${ }^{3)}$ \\ ${ }^{1)}$ Teknik Informatika, Universitas Indraprasta Pgri, Jakarta Selatan \\ ${ }^{2)}$ Pendidikan Fisika, Universitas Indraprasta Pgri, Jakarta Selatan \\ ${ }^{3)}$ Pendidikan Matematika, Universitas Indraprasta Pgri, Jakarta Selatan \\ ${ }^{*}$ Email: erlinunindra@gmail.com
}

\begin{abstract}
ABSTRAK
Kegiatan pertambangan dapat merubah keadaan lapisan permukaan bumi, sehingga kemungkinan besar memiliki dampak resiko kebencanaan yang tinggi. Hal ini tentunya dapat mengancam dan mengganggu keselamatan jiwa manusia, serta kerusakan lingkungan. Lokasi pertambangan yang umumnya banyak mengandung bentonit terdapat di daerah Desa Birowo, Kecamatan Binangun, Blitar juga tidak terlepas dari dampak resiko kebencanaan. Untuk penentuan titik rawan bencana di wilayah pertambangan tersebut dilakukan analisa menggunakan Analytic Network Process (ANP) dengan mempertimbangkan antar kriteria dan sub kriteria dari lingkungan tambang yang saling berkaitan sehingga penanganan dan penanggulangan daerah tambang di wilayah tersebut dapat ditindaklanjuti. Daerah yang mempunyai resiko kebencanaan tertinggi dari analisis ANP tersebut adalah TP-7, TP-8, TP-9, TP-10 (Birowo2) dikarenakan bentonit di lokasi ini jenis tanahnya alluvial lunak, serta berada pada formasi komplek sehingga diperlukan adanya ketelitian dan kehati-hatian dalam hal pelaksanaan teknik pertambangannya.
\end{abstract}

Kata Kunci : Kegiatan pertambangan, resiko kebencanaan, ANP

\section{PENDAHULUAN}

Indonesia mempunyai aset kekayaan alam yang begitu besar untuk dikelola dan dimanfaatkan, baik dari pemerintahan daerah maupun masyarakat sekitarnya, terutama di sektor pertambangan. Namun, kegiatan penambangan kenyataannya dapat merubah keadaan lapisan permukaan bumi, sehingga kemungkinan besar memiliki dampak resiko kebencanaan yang tinggi. Hal ini tentunya dapat mengancam dan mengganggu keselamatan jiwa manusia, serta kerusakan lingkungan, merajuk kepada peraturan undang-undang no 24 tahun 2007.

Kabupaten Blitar, Provinsi Jawa Timur, terletak pada koordinat $112^{\circ} 18^{\prime} 20^{\prime}$ BT dan $8^{\circ} 12^{\prime} 09^{\prime \prime}$ LS - $8^{\circ} 05^{\prime} 15^{\prime \prime}$ LS. Struktur geomorfologi batuannya terdiri dari 14 jenis yaitu (dari muda ke tua) (Gambar 1): aluvium (Qa), endapan lahar (Qvlh), endapan gunung kelud (Qvk), endapan tuf (Qptm), batuan gunung api kelud tua(Qpvk), lava andesit parasit (Q1k), endapan Gunungapi Butak (Qpkb), formasi Wonosari (Tmwl), formasi Nampol (Tmn), formasi Wuni (Tmw), formasi Campurdarat (Tmcl), anggota Tuf Mandalika(Tomt), formasi Mandalika (Tomm), batuan trobosan (Tomi). Di wilayah ini merupakan lokasi pertambangan yang umumnya banyak mengandung bentonit untuk bahan baku keramik (bahkan ditemukan bahan 
penjernih minyak kelapa sawit) dan terdapat di daerah Desa Birowo, Kecamatan Binangun, Blitar.

Untuk penentuan titik rawan bencana di wilayah pertambangan tersebut dilakukan analisa menggunakan Analytic Network Process (ANP) dengan mempertimbangkan antar kriteria dan sub kriteria dari lingkungan tambang yang saling berkaitan sehingga penanganan dan penanggulangan daerah tambang di wilayah tersebut dapat ditindak lanjuti.
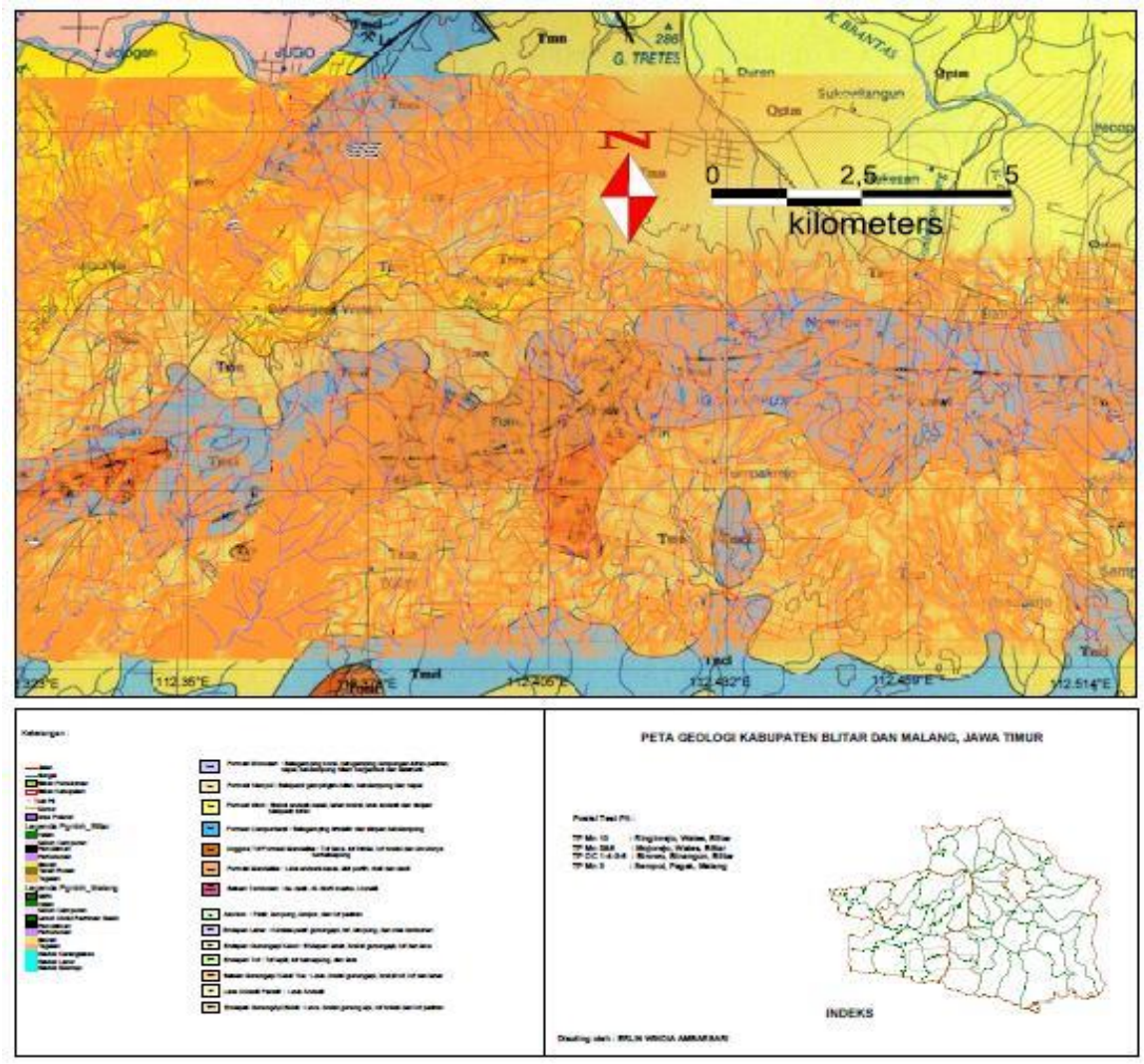

Gambar 1. Lokasi potensi bentonit Kabupaten Blitar (Lembar peta geologi Kabupaten Blitar, Jawa Timur, P3G, 1995 )

\section{METODE PENELITIAN}

\section{Analytic Network Process (ANP)}

Analytic Network Process (ANP) merupakan salah satu metode yang mampu merepresentasikan tingkat kepentingan berbagai pihak dengan mempertimbangkan saling keterkaitan antar kiteria dan sub kiteria (Vanany, 2003). Metode ANP diperkenalkan oleh Prof. Thomas Saaty sebagai bentuk penyempurnaan metode Analytic Hierarchy Process (AHP). Metode ANP merupakan pengembangan dari ANP sehingga lebih memiliki kompleksitas dan kemampuan mengakomodasi keterkaitan antar kriteria atau alternatif. Konsep ANP berasal dari teori AHP yang didasarkan pada hubungan yang saling 
ketergantungan antara beberapa komponen, sehingga AHP merupakan bentuk khusus dalam ANP.

\section{Konsep ANP}

Pembobotan ANP membutuhkan model yang merepresentasikan saling keterkaitan antar kriteria dan sub kriteria yang dimiliki. Ada dua kontrol yang perlu diperhatikan di dalam memodelkan sistem yang hendak diketahui bobotnya. Kontrol pertama adalah hierarki yang menunjukkan keterkaitan kriteria dan sub kriterianya. Kontrol lainnya adalah kontrol keterkaitan yang menunjukkan adanya saling keterkaitan antar kriteria atau cluster.

Jika diasumsikan suatu sistem memiliki $\mathrm{N}$ cluster atau komponen dimana elemenelemen dalam tiap komponen saling berinteraksi atau memiliki pengaruh atau dipengaruhi oleh beberapa atau seluruh elemen dari komponen lain dengan mempertimbangkan interaksi seluruh sistem, dan jika komponen $h$ dinotasikan dengan $C_{h}$ dimana $h=1,2,3, \ldots, \mathrm{N}$ mempunyai $n_{h}$ elemen yang dinotasikan dengan $\mathrm{e}_{\mathrm{h} 1}, \mathrm{e}_{\mathrm{h} 2}, \ldots, \mathrm{e}_{\mathrm{hnh}}$ maka pengaruh dari satu set elemen dalam suatu komponen pada elemen yang lain dalam suatu sistem dapat direpresentasikan melalui vektor prioritas berskala rasio yang diambil dari perbandingan berpasangan. Tiap vektor prioritas ditempatkan dalam posisi vektor dalam suatu supermatrik dengan format sebagai berikut :

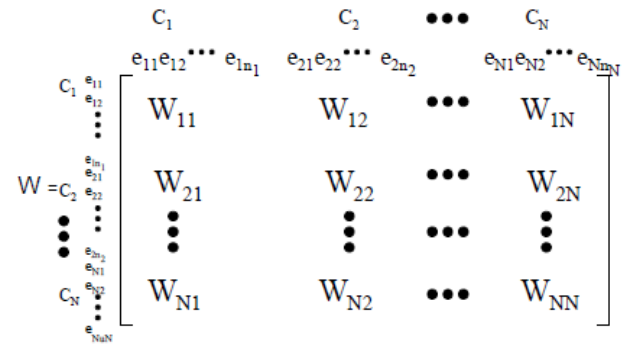

dimana blok $i, j$ dari matrik tersebut adalah :

$$
\mathrm{W}_{\mathrm{ij}}=\left[\begin{array}{cccc}
\mathrm{W}_{\mathrm{i} 1}^{\left(\mathrm{j}_{1}\right)} & \mathrm{W}_{\mathrm{i} 1}^{\left(\mathrm{j}_{1}\right)} & \cdots & \mathrm{W}_{\mathrm{i} 1}^{\left(\mathrm{in}_{1}\right)} \\
\mathrm{W}_{\mathrm{i} 2}^{\left(\mathrm{j}_{1}\right)} & \mathrm{W}_{\mathrm{i} 2}^{\left(\mathrm{j}_{2}\right)} & \cdots & \mathrm{W}_{\mathrm{i} 2}^{\left(\mathrm{in}_{\mathrm{j}}\right)} \\
\vdots & \vdots & & \vdots \\
\mathrm{W}_{\mathrm{in}_{\mathrm{i}}}^{\left(\mathrm{j}_{1}\right)} & \mathrm{W}_{\mathrm{in}_{\mathrm{i}}}^{\left(\mathrm{j}_{2}\right)} & \cdots & \mathrm{W}_{\mathrm{in}_{\mathrm{i}}}^{\left(\mathrm{ji}_{\mathrm{j}}\right)}
\end{array}\right]
$$

Setiap kolom merupakan eigenvector prinsipal yang menggambarkan pengaruh dari seluruh elemen dalam komponen $i_{t h}$ pada tiap elemen dalam komponen $j_{t h}$.

\section{Tahap-tahap ANP}

Tahap pengambilan keputusan dengan ANP (Utomo, 2009) antara lain : 
1. Kontruksi model dan permasalahannya

Masalah perlu distrukturkan ke dalam komponen-komponen penting. Kriteria yang relevan dan alternatif distrukturkan ke dalam bentuk suatu hierarki yang mana semakin tinggi levelnya maka semakin startegis keputusannya.

2. Pembentukan matrik-matrik perbandingan berpasangan dari level-level komponen yang saling ketergantungan

Pengambilan keputusan diminta untuk merespon suatu perbandingan berpasangan (pairwise comparison) dengan melihat komponen setiap level dengan mempertimbangkan kepentingan relatif terhadap kriteria kontrol. Kriteria kontrol digunakan untuk perbandinganperbandingan berpasangan berupa kriteria pada level yang lebih tinggi maupun level yang paling rendah. Pengukurannya menggunakan skala Saaty dari 1-9.

Skala 1 menunjukkan dua pilihan yang mempunyai tingkat kepentingan yang sama atau tidak ada perbedaan, dan skala 9 menunjukkan dominasi yang sangat besar dari suatu komponen yang dipertimbangkan terhadap komponen pembanding. Ketika penilaian skala dilakukan untuk suatu pasangan, suatu nilai kebalikan secara otomatis merupakan perbandingan kebalikan di dalam matrik. Jika $a_{i j}$ merupakan suatu nilai dalam matrik yang menunjukkan hubungan antara komponen atau terhadap komponen, maka $a_{i j}=1 / a_{j i}$ atau $a_{i j} \cdot a_{j i}$ $=1$. Jika perbandingan berpasangan telah lengkap, vektor prioritas $\mathrm{w}$ (eigenvector) dihitung dengan rumus :

$A \cdot w=\lambda \max . w$

$A$ adalah matrik perbandingan berpasangan dan $\lambda_{\max }$ adalah eigenvalue terbesar dari $A$.

Eigenvector merupakan bobot prioritas suatu matrik yang kemudian digunakan dalam penyusunan supermatrik.

\section{Perhitungan Rasio Konsistensi}

Indek Konsistensi $(C I)$ dan Rasio Konsistensi $(C R)$ pada matrik perbandingan berpasangan dihitung dengan rumus :

$C I=\frac{(\lambda \max -n)}{(n-1)}, C R=\frac{C I}{R I}$

$R I$ merupakan indeks konsistensi acak yang dibangun oleh Saaty. Umumnya jika $C I<0,1$ maka penilaian dianggap konsisten (Navarro dkk., 2009).

4. Formasi supermatrik

ANP mengggunakan formasi dari suatu supermarik untuk memberikan resolusi pengaruh ketergantungan antar kelompok (cluster) dari hierarki jaringan keputusan, antara lain : 
a. Unweighted supermatrix, merupakan matrik awal yang tersusun dari kolom eigenvector perbandingan berpasangan dari setiap elemen kriteria.

b. Weighted supermatrix, merupakan supermatrik awal yang kemudian dikalikan dengan matrik cluster. Pada setiap kolom matrik ini merupakan komponen pengaruh kriteria pada kriteria pada kriteria tujuan.

c. Limit supermatrix, diperoleh dengan memangkatkan weighted supermatrix dengan suatu bilangan yang besar sehingga stabil dimana nilai-nilai dalam supermatrik tidak berubah ketika dikalikan dengan dirinya sendiri lagi atau disebut dengan konvergen. Limit supermatrix digunakan sebagai penentuan bobot akhir.

5. Pemilihan alternatif terbaik

Pemilihan alternatif terbaik didapatkan dari limit supermatrix. Alternatif yang dipilih adalah alternatif yang memiliki nilai terbesar.

Berdasarkan rujukan pada penelitian sebelumnya (Parwatiningtyas dkk., 2013) dan (Ambarsari dan Herusantoso, 2011), maka tahap-tahap ANP pada penelitian ini dapat lihat pada Gambar 2.

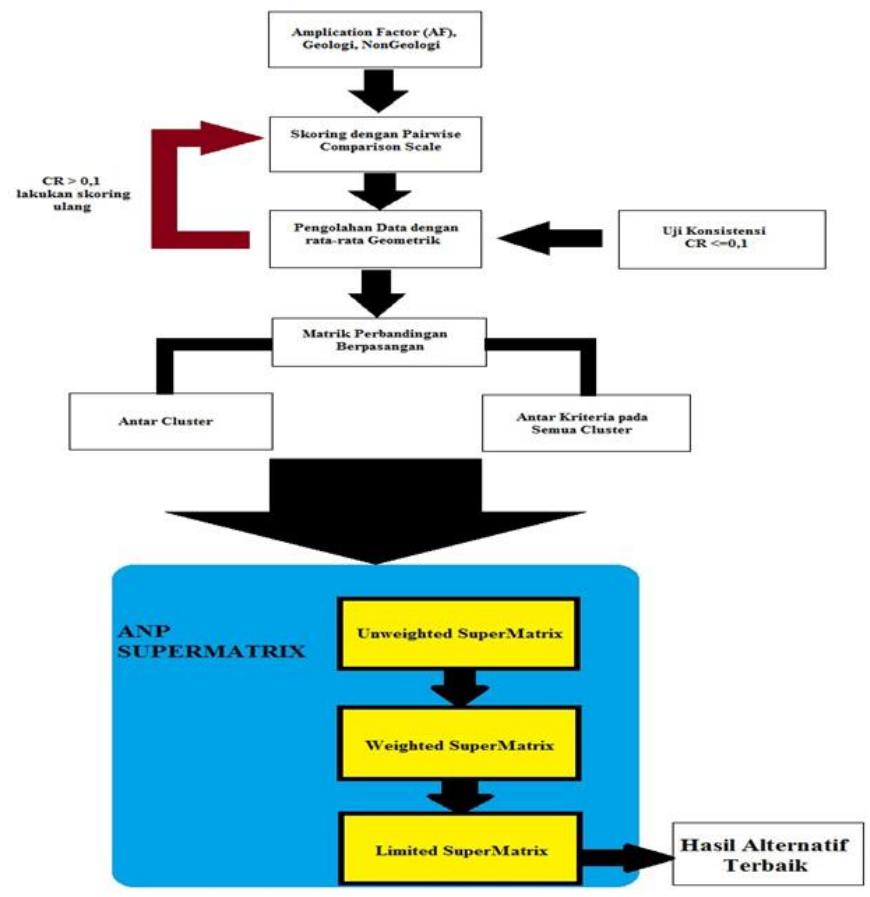

Gambar 2. Tahap-tahap ANP

\section{HASIL DAN PEMBAHASAN}

Lokasi pertambangan bentonit di Desa Birowo (Gambar 3) yang diambil dalam penelitian ini terbagi menjadi 3 kelompok alternatif, yaitu :

a. Birowo1, terdiri dari 6 track point (TP-1 s/d TP-6) 
b. Birowo2, terdiri dari 4 track point (TP-7 s/d TP-10)

c. Ringinrejo, terdiri dari 5 track point (TP-11 s/d TP-15)

Setiap titik dikalkulasi dengan menggunakan amplication factor (AF) dari analisis microtremor. Hasil AF tersebut dijadikan sebagai pertimbangan untuk menentukan kriteria ANP. Selain itu juga pengamatan di sekitar lingkungan pertambangan baik dari sisi geologi maupun nongeologi menjadi pertimbangan kriteria di dalam ANP. Kriteria-kriteria tersebut dianalisa ke dalam pemodelan ANP seperti pada Gambar 4.

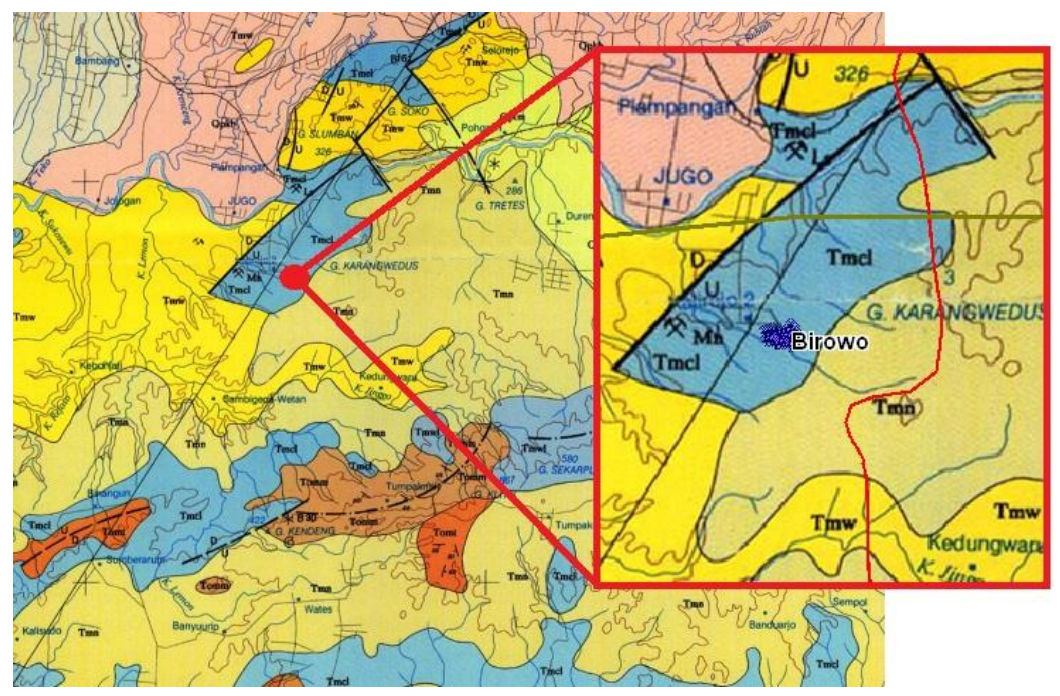

Gambar 3. Lokasi pertambangan Bentonit Desa Birowo, Kecamatan Binangun, Blitar

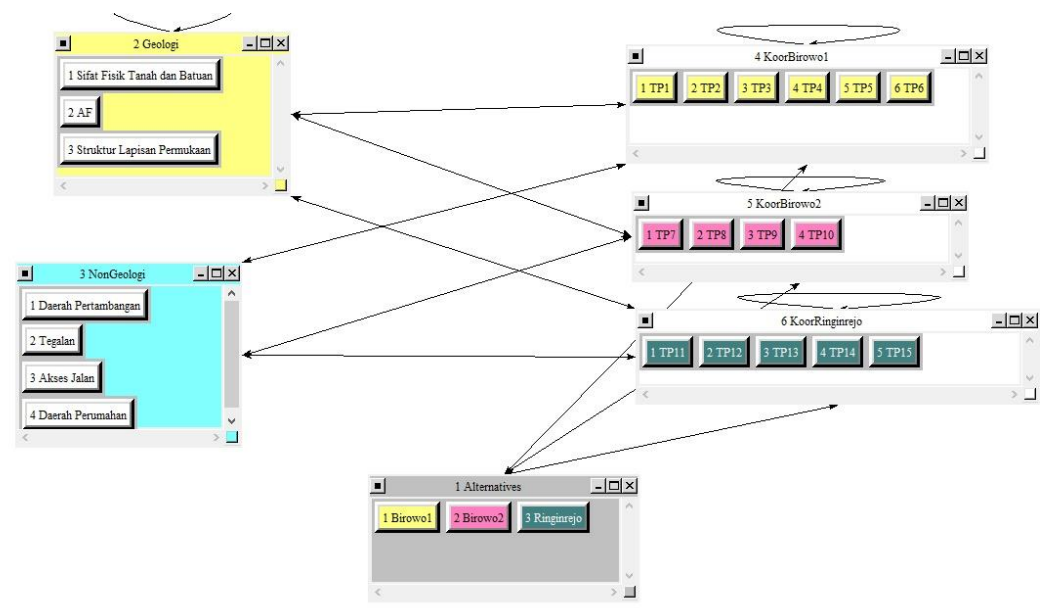

Gambar 4. Model ANP

Hasil yang didapatkan dari penelitian ini dalam penanganan resiko kebencanaan adalah sebagai berikut :

1. Geologi 
Prioritas resiko kebencanaan yang akan dianalisa pertama kali adalah sifat fisik tanah dan batuan (bobot prioritas tertinggi 0,41341) yang terdapat di lingkungan pertambangan yang dikarenakan perubahan bentonitnya itu sendiri baik secara fisik dan kimiawi. Secara fisik, bentonit menjadi permeable dan mudah mengembang, sedangkan ditinjau dari komposisi kimianya, bentonit ini yang batuan asalnya yaitu berupa tuf dari batuan vulkanik, akibat deformasi, dia akan cenderung berubah warna menjadi hijau (kristal ferromagnesian), coklat dan merah, yang kaya akan asam (acid).

Prioritas berikutnya adalah dilihat dari struktur lapisan permukaan $(0,31685)$ dan AF $(0,26974)$, hal ini dikarenakan ada kemungkinan pergeseran lapisan permukaan dan tanah (deformation and geodynamic) serta penurunan lapisan permukaan secara tiba-tiba (subsidence), sehingga memungkinkan adanya rawan bencana seperti amblesan secara mendadak ataupun longsoran. Tingkatan prioritas geologi tersebut disajikan pada gambar 5 .

2. Non Geologi

Akses jalan menuju pertambangan di Desa Birowo mendapatkan bobot prioritas tertinggi yaitu 0,29941. Hal tersebut disebabkan lapisan permukaannya miring (slope), perlu kehati-hatian saat membuka akses jalan karena ada beberapa lokasi yang tidak stabil sehingga mudah sekali terjadi longsoran (Gambar 6).

\begin{tabular}{|c|ccc|}
\hline $\begin{array}{c}\text { 1 Sifat Fisik Tanah dan } \\
\text { Batuan }\end{array}$ & \multicolumn{1}{c|}{0.41341} & 0.118596 \\
\hline 2 AF & \multicolumn{1}{c|}{0.26974} & 0.077379 \\
\hline $\begin{array}{c}\text { 3 Struktur Lapisan } \\
\text { Permukaan }\end{array}$ & & 0.31685 & 0.090895 \\
\hline
\end{tabular}

Gambar 5. Prioritas Geologi

\begin{tabular}{|c|c|c|}
\hline 1 Daerah Pertambangan & 0.19150 & 0.034761 \\
\hline 2 Tegalan & 0.27273 & 0.049506 \\
\hline 3 Akses Jalan & 0.29441 & 0.053442 \\
\hline 4 Daerah Perumahan & 0.24136 & 0.043812 \\
\hline
\end{tabular}

Gambar 6. Prioritas NonGeologi

\section{Track Point (TP)}

Berdasarkan gambar 7, TP-7 s/d TP-10 secara keseluruhan mengalami perubahan yang segnifikan dibandingakan TP yang lain. Hal ini disebabkan karena bentonit di lokasi ini jenis tanahnya adalah alluvial lunak, serta berada pada formasi komplek. Sehingga amblesan 
secara mendadak, longsoran, pergeseran lapisan permukaan dan tanah, penurunan lapisan permukaan secara tiba-tiba cukup tinggi.

\begin{tabular}{|c|c|c|}
\hline $1 \mathrm{TP} 1$ & 0.19850 & 0.027069 \\
\hline $2 \mathrm{TP} 2$ & 0.18945 & 0.025835 \\
\hline 3 TP3 & 0.15826 & 0.021581 \\
\hline 4 TP4 & 0.16835 & 0.022957 \\
\hline 5 TP5 & 0.15525 & 0.021170 \\
\hline 6 TP6 & 0.13019 & 0.017753 \\
\hline 1 TP7 & 0.28818 & 0.069349 \\
\hline 2 TP8 & 0.17788 & 0.042805 \\
\hline 3 TP9 & 0.31247 & 0.075194 \\
\hline 4 TP10 & 0.22148 & 0.053297 \\
\hline 1 TP11 & 0.15088 & 0.020599 \\
\hline 2 TP12 & 0.21597 & 0.029485 \\
\hline 3 TP13 & 0.20745 & 0.028322 \\
\hline 4 TP14 & 0.15849 & 0.021638 \\
\hline 5 TP15 & 0.26721 & 0.036480 \\
\hline
\end{tabular}

Gambar 7. Track Point (TP) masing-masing lokasi pertambangan

Oleh karena itu TP-7 s/d TP-10 yaitu lokasi Birowo2 (0,39928) diperlukan adanya penanganan khusus, ketelitian dan kehati-hatian dalam hal pelaksanaan teknik pertambangannya (Gambar 8).

\begin{tabular}{|l|l|l||l||c|}
\hline \multicolumn{1}{|c|}{ Name } & Graphic & Ideals & Normals & Raw \\
\hline \hline 1 Birowo1 & & 0.799038 & 0.319050 & 0.005767 \\
\hline \hline 2 Birowo2 & & 1.000000 & 0.399292 & 0.007217 \\
\hline \hline 3 Ringinrejo & & 0.705394 & 0.281658 & 0.005091 \\
\hline
\end{tabular}

\section{Alternative Rankings}

\begin{tabular}{|c||c|c|c|c|c|}
\hline Graphic & Alternatives & Total & Normal & Ideal & Ranking \\
\hline \hline & 1 Birowo1 & 0.0058 & 0.3190 & 0.7990 & 2 \\
\hline \hline & 2 Birowo2 & 0.0072 & 0.3993 & 1.0000 & 1 \\
\hline \hline & 3 Ringinrejo & 0.0051 & 0.2817 & 0.7054 & 3 \\
\hline
\end{tabular}

Gambar 8. Peringkat Lokasi Pertambangan Resiko Kebencanaan 


\section{KESIMPULAN}

Berdasarkan hasil pengolahan data serta analisis yang telah dilakukan, maka dapat diperoleh beberapa kesimpulan sebagai berikut:

1. Mengamati resiko kebencanaan yang didahulukan adalah sifat fisik tanah dan batuan $(0,41341)$, kemudian struktur lapisan permukaan $(0,31685)$, dan amplication factor $(0,26974)$.

2. Ada beberapa lokasi tidak stabil dikarenakan lapisan permukaannya miring (slope), sehingga mudah sekali terjadi longsoran. Perlu kehati-hatian saat membuka akses jalan $(0,29441)$.

3. Lokasi pertambangan yang mempunyai resiko kebencanaan cukup besar adalah Birowo2 (0,39928) yaitu TP-7 s/d TP-10, sehingga perlu penanganan khusus, dalam hal pelaksanaan teknik pertambangannya.

\section{UCAPAN TERIMA KASIH}

Penulis mengucapkan terima kasih kepada Tuhan YME dan juga berkat pihak panitia SENAFIS dimana kesempatan yang telah diberikan melalui skim Penelitian Fundamental.

\section{DAFTAR PUSTAKA}

Ambarsari, Erlin W., dan Herusantoso, Khamami. 2011. Analisa Penentuan Layak Tambang Bentonit Provinsi Jawa Timur Dengan ANP, Prosiding SNTI Universitas Tarumanegara Jakarta, ISSN : 1829-9156, Vol. 8 No. 1, pp.17-21.

Badan Standarisasi Nasional. 1998. Klasifikasi Sumberdaya Mineral dan Cadangan, Amandemen 1-SNI13-4726-1988, ICS 73.020, Standar Nasional Indonesia.

Navarro, T. G., Melon, M. G., Martin, D. D., dan Dutra, S. A. 2009. Evaluation of urban development proposals An ANP approach. International Journal of Human and Social Science, 4:7, pp. 537-547.

Saaty, Thomas L., dan Vargas, Luis G. 2006. Decision Making With The Analytic Network Process, New York, Springer.

Parwatiningtyas, Diyan., Ambarsari, Erlin W., Marlina, Dwi., dan Wiratomo, Yogi. 2013. Calculation Of Disaster Risk Value In The Prospect Mining Area, Blitar District, East Java Using Microtremor Analysis. The $3^{\text {rd }}$ International Symposium For Sustainable Humanosphere (ISSH), ISSN : 2088-9127, pp. 46-55.

Utomo, Wahyu E. P. 2009. Pemodelan Generik Balanced Scorecard dan Hoshin Kanri yang memiliki Kemampuan untuk Menyelaraskan Dinamika Manajemen Strategi pada 
Industri Alat Berat, Fakultas Teknik, Program Pascasarjana Teknik Industri, Universitas Indonesia, Jakarta.

Vanany, Iwan. 2003. Aplikasi Analytical Network Process (ANP) pada Perancangan Sistem Pengukuran Kinerja (Studi Kasus pada PT X). 